\title{
PELAKSANAAN KEGIATAN PELAYANAN KELILING PEREKAMAN E-KTP DI KECAMATAN TANJUNG LAGO KABUPATEN BANYUASIN
}

\author{
Oleh : \\ Siti Zubaidah ${ }^{1}$ \\ Rusdi Laili ${ }^{2}$ \\ Dian Kristiawan ${ }^{3}$ \\ STIA Bala Putra Dewa Palembang 1,2 dan 3 \\ siti39196@gmail.com ${ }^{1}$ \\ rusdilaili01@gmail.com ${ }^{2}$ \\ $\underline{\text { m.dian25121982@gmail.com }}{ }^{3}$
}

\begin{abstract}
ABSTRAK
Penelitian ini bertujuan untuk mengetahui Pelaksanaan Kegiatan Perekaman Keliling E-KTP di Kecamatan Tanjung Lago, Hambatan dalam kegiatan perekaman E-KTP adalah mesin cetak. Daerah belum diberi wewenang untuk mencetak E-KTP mereka sendiri, karena otoritas masih di pusat. Atas dasar permasalahan diatas aparatur pemerintah khususnya di Kecamatan Tanjung Lago Kabupaten Banyuasin melakukan pelayanan keliling perekaman E-KTP untuk membantu dan mempermudah masyarakat dalam proses. Penelitian ini menggunakan metode kualitatif dengan teknik observasi dan wawancara langsung pada informan. Kesimpulan dari penelitian ini adalah Masih adanya masyarakat yang belum mempunyai E-KTP karena Masyarakat di Kecamatan Tanjung Lago terkesan malas untuk melakukan perekaman e-ktp dan terkait mesin cetak yang masih di pusat serta masih adanya keluhan terhadap pelayanan yang kurang ramah dari aparatur pemerintahan di Kecamatan Tanjung Lago untuk itu diperlukan sarana prasarana untuk menunjang proses perekaman e-ktp di Kecamatan Tanjung Lago disediakan terutama Pemerintah Pusat harus menyediakan alat cetak e-ktp di setiap Kecamatan dan juga aparatur sipil Negara yang ramah melayani permasalahn masyarakat.
\end{abstract}

Kata Kunci : Pelaksanaan, Kegiatan Pelayanan Keliling, Perekaman E-KTP

ABSTRACT

This study discusses the implementation of Mobile Recording E-Identity Card Service Activities in Tanjung Lago District, One of which supports the implementation of the E-Identity Card is a printing press. The regions do not yet have permission to choose their own E-Identity Card because the current authority is still at the Center. On the basis of the above problems, a special government apparatus in Tanjung Lago Subdistrict, 
Banyuasin District, did a recording of the E-Identity Card to help and facilitate the community in the process. This study uses a qualitative method with observation techniques and direct interviews with informants. The conclusion of this study is that there are still people who do not have an E-Identity Card because the people in Tanjung Lago District are happy to record e-ID Card and related printing machines that are still at the center and there are still responses to the government that are less friendly from the government apparatus in Tanjung District, For this reason, infrastructure facilities to support the e-ID card recording process in Tanjung Lago Subdistrict are provided by the central government.

Keywords: Implementation, Mobile Services Activities, E-ID Card Recording

\section{A. Pendahuluan}

KTP Elektronik adalah sebuah kartu kependudukan yang dilengkapi dengan sistem keamanan dari perspektif manajemen dan teknologi informasi berdasarkan pada basis data populasi nasional.

Dasar hukum Pembuatan E-KTP merujuk pada Undang - Undang Republik Indonesia Nomor 23 Tahun 2006 tentang Administrasi Kependudukan, dijelaskan bahwa: "Penduduk hanya diperbolehkan memiliki 1 (satu) KTP yang tercantum Nomor Induk Kependudukan (NIK). NIK merupakan identitas tunggal setiap penduduk dan berlaku seumur hidup".

Tufoksi terpenting pemerintah adalah pemberian pelayanan yang baik kepada masyarakat. Semua warga negara membutuhkan pelayanan pemerintah atau birokrat sebagai penguasa kekuasaan. Berdasarkan Undang-Undang 25 tahun 2009, pelayanan publik diartikan sebagai kegiatan dalam memenuhi kebutuhan pelayanan bagi setiap warga negara dan penduduk atas barang, jasa, dan/atau pelayanan administratif yang disediakan oleh penyelenggara pelayanan publik.

Di Indonesia dalam Pengurusan e-KTP di seluruh kecamatan tanpa dipungut biaya administrasi, sehingga masyarakat untuk segera mengurus dan mendapatkan e-KTP tersebut. Namun, dalam pelayanan pengurusan e-KTP ini, di Kecamatan Tanjung Lago ditemukan permasalahan di lapangan yang dilakukan petugas di Kecamatan. permasalahan ini antara lain seperti masyarakat yang mendatangi kantor camat untuk mengurus e-KTP sesuai jadwal yang telah ditetapkan, ternyata tidak mendapatkan pelayanan maksimal.

Layanan Keliling Rekam e KTP berlangsung di Kantor Camat Tanjung Lago di Jl. Tanjung Api-Api Km 9,5. Dalam proses pelaksanaan pelayanan keliling dalam perekaman e-KTP di Kecamatan Tanjung Lago masih dijumpai beberapa kelemahan dan permasalahan seperti operator 
pelayanan terbatas dan proses perekaman yang melebihi jam kerja Kecamatan, bahkan kelelahan operator terkadang menimbulkan kekeliruan data yang di input. Beberapa masyarakat atau aparatur pemerintah terbatas pada distribusi e-KTP, dan aktivasi dilakukan di esok harinya, sebagai akibatnya masyarakat yang jauh dari instansi pemerintah malas untuk datang ke instansi. Kekeliruan lain oleh operator adalah kesalahan foto dengan data. Ini mungkin karena kesalahan operator secara tidak sengaja memasukkan data populasi ketika proses registrasi data untuk e-KTP dan E-KTP tidak dibaca oleh versi lama dari pembaca kartu.

Seluruh rantai proses pelayanan dan penerbitan harus sesuai disupervisi secara ketat dan benar agar tidak ada penyalahgunaan pelayanan e-KTP, selain itu, tim supervisi perlu memahami alur proses supervisi supaya proses perekaman data penduduk dan pengiriman data hasil perekaman di daerah berjalan lancar secara baik dan benar. Selain itu, perlu secara keseluruhan dapat ditinjau permasalahan teknis dan non teknis yang terjadi dan memberikan masukan rekomendasi pemecahan masalah kepada Ditjen Kependudukan dan Pencatatan Sipil (Dukcapil).

Berdasarkan pendahuluan, peneliti menuangkan keingintahuan dalam rumusan masalah Bagaimana Pelaksanaan Kegiatan Pelayanan Keliling Perekaman E-KTP di Kecamatan Tanjung Lago? serta manfaat dari hasil penelitian ini diharapkan dapat memberikan gambaran yang jelas mengenai Analisis Pelaksanaan Kegiatan Pelayanan Keliling Perekaman E-KTP di Kecamatan Tanjung Lago dan dapat menambah ilmu pengetahuan dan dijadikan bahan kajian yang bermanfaat bagi para akademisi untuk penelitian lebih lanjut juga sebagai bahan masukan bagi pihak-pihak atau instansi terkait yang berkompeten dalam melakukan usaha-usaha menganalisis Pelaksanaan Kegiatan Pelayanan Keliling Perekaman E-KTP di Kecamatan Tanjung Lago, dan juga memberikan informasi bagi pihak-pihak yang membutuhkan data-data tentang Pelaksanaan Kegiatan Pelayanan Keliling Perekaman E-KTP di Kecamatan Tanjung Lago.

\section{Pelaksanaan}

Pelaksanaan merupakan kegiatan yang dilaksanakan oleh suatu badan atau wadah secara berencana, teratur dan terarah guna mencapai tujuan yang diharapkan. Keberhasilan suatu kegiatan atau karyawan tergantung pada manajemen. Pekerjaan akan berhasil jika manajemen terorganisasi dengan baik dan terorganisir, manajemen mana pun sebagai alat dengan melakukan proses tertentu dalam fungsi terkait. Intinya adalah bahwa berbagai tahap kegiatan berkisar dari awal kegiatan atau 
pekerjaan hingga akhir pencapaian kegiatan atau pekerjaan. Apa yang diketahui beberapa ahli tentang manajemen? berikut penjelasannya:

Pengertian / Teori manajemen menurut beberapa ahli adalah sebagai berikut :

1. Menurut Terry (2000:45) : Manajemen sebagai proses atau kerangka kerja, yang mencakup instruksi atau arahan sekelompok orang ke dalam tujuan atau sasaran organisasi yang realistis.

2. Richard (2002:67) Manajemen merupakan gerakan pengelolaan karyawan-karyawan dan mengarahkan semua fasilitas kerja untuk tujuan organisasi agar benar-benar tercapai.

3. Siagian pada "Filsafat Administrasi" Manajemen dapat diartikan keterampilan atau kemampuan untuk mendapatkan suatu hasil dalam pencapaian tujuan melalui orang lain.

Menurut Terry (2006: 9-15) fungsi manajemen adalah serangkain kegiatan atau tugas memanage yang mempunyai peranan khas dan bersifat saling berhubungan dalamm mencapai tujuan yang ditetapkan sebelumnya. Terry menyatakan bahwa fungsi-fungsi fundamental pengelolaan meliputi hal-hal sebagai berikut yaitu perencanaan (planning), pengorganisasian (organizing), menggerakkan (actuating), mengawasi (controlling), atau disingkat POAC.

a. Perencanaan adalah Pemikiran logis dan rasional didasarkan pada data atau informasi sebagai dasar untuk kegiatan organisasi, manajemen dan individu untuk mencapai tujuan mereka. Perencanaan adalah keputusan tentang pekerjaan yang harus dilakukan kelompok untuk mencapai tujuannya. Rencana tersebut mencakup kegiatan pengambilan keputusan karena mencakup pengambilan keputusan. Mengembangkan pola tindakan berwawasan ke depan membutuhkan kemampuan untuk berefleksi dan berpikir positif.

b. Pengorganisasian (Organizing) ialah terkait dengan pembagian tugas. Siapa yang melakukan apa dan siapa yang bertanggung jawab untuk itu. Penyelenggara adalah proses mempersiapkan struktur organisasi mereka sesuai dengan tujuan organisasi, sumber daya dan lingkungan mereka.

c. Penggerakan/Pelaksanaan (Actuating) ialah usaha menggerakaan anggota organisasi sehingga mereka berusaha dan berkeinginan untuk mencapai sasaran baik perusahaan maupun anggota. Karenanya para anggota juga ingin mencapai sasaran-sasaran tersebut. Penggerakan merupakan fungsi manajemen yang berhubungan dengan bagaimana cara menggerakkan kerabat kerja (bawahan) agar bekerja dengan penuh kesadaran tanpa paksaan.

d. Pengawasan (Controlling) ialah semua pekerjaan yang dilakukan dilakukan sesuai dengan rencana yang ditetapkan sebagai suatu 
proses pemantauan pelaksanaan semua kegiatan organisasi untuk memastikan bahwa. Ukuran pengawasan seperti yang direncanakan, mulai perencanaan yang dapat direncanakan dan pengawasan adalah dua sisi dari koin yang sama.

\section{Pelayanan}

Menurut Poerwadarminta dalam Hardiyansyah (2011:10-11) berpendapat bahwa:

"secara etimologis pelayanan berasal dari kata layan yang berarti membantu menyiapkan atau mengurus apa-apa yang diperlukan seseorang, kemudian pelayanan dapat diartikan sebagai: Perihal atau cara melayani; Servis atau jasa; Sehubungan dengan jual beli barang atau jasa. Dari uraian tersebut, maka pelayanan dapat diartikan sebagai aktivitas yang diberikan untuk membantu, menyiapkan dan mengurus baik itu berupa barang atau jasa dari satu pihak kepada pihak lain".

Pelayanan umum atau pelayanan publik menurut Wasistiono dalam Hardiyansyah (2011:11) adalah pemberian jasa, baik oleh pemerintah, pihak swasta atas nama pemerintah atau pun pihak swasta kepada masyarakat, dengan atau tanpa pembayaran guna memenuhi kebutuhan dan atau kepentingan masyarakat. Berbeda dengan pendapat di atas, Ratminto dan Winarsih (2005:5) berpendapat bahwa:

"pelayanan publik atau pelayanan umum sebagai segala bentuk jasa pelayanan, baik dalam bentuk barang publik maupun jasa publik yang pada prinsipnya menjadi tanggungjawab dan dilaksanakan oleh instansi pemerintah di pusat, di daerah, dan lingkungan Badan Usaha Milik Negara (BUMN) atau Badan Usaha Milik Daerah (BUMD), dalam upaya pemenuhan kebutuhan masyarakat maupun dalam rangka pelaksanaan ketentuan peraturan perundang-undangan".

Sedangkan pelayanan umum menurut Moenir (2010:26) adalah kegiatan yang dilakukan oleh seorang atau sekelompok orang dengan landasan faktor materiel melalui sistem, prosedur dan metode tertentu dalam rangka usaha memenuhi kepentingan orang lain sesuai dengan haknya.

Sinambela (2011:5) berpendapat bahwa:

"pelayanan publik adalah pemenuhan keinginan dan kebutuhan masyarakat oleh penyelenggara negara. Negara didirikan oleh publik (masyarakat) tentu saja dengan tujuan agar dapat meningkatkan kesejahteraan masyarakat. Pada hakikatnya Negara dalam hal ini pemerintah (birokrat) haruslah dapat memenuhi kebutuhan masyarakat. Kebutuhan dalam hal ini bukanlah 
kebutuhan secara individual, akan tetapi berbagai kebutuhan yang sesungguhnya diharapkan oleh masyarakat, misalnya kebutuhan akan kesehataan, pendidikan, dan lain lain".

Berdasarkan beberapa pendapat di atas, dapat ditarik simpulan bahwa pelayanan publik adalah kegiatan menyediakan layanan oleh penyedia layanan publik, yaitu pemerintah, BUMN, atau BUMD yang dilakukan sesuai dengan prinsip dan prinsip layanan publik dan ketentuan hukum untuk memenuhi kebutuhan publik dalam bentuk barang publik dan layanan publik dalam rangka meningkatkan kesejahteraan masyarakat.

\section{E-KTP (Kartu Tanda Penduduk Elektronik)}

Saat ini masih banyak terdapat satu orang yang sama memiliki lebih dari satu Kartu Keluarga (KK) ataupun KTP yang berbeda-beda tentunya kondisi seperti ini berdampak merugikan orang lain dan bahkan tidak jarang pula merugikan pemerintah. Berdasarkan Undang-Undang Nomor 23 Tahun 2006 tersebut diharapkan sudah tidak ada lagi penduduk yang mempunyai Kartu Tanda Penduduk ataupun kartu keluarga yang lebih dari satu.

Menindaklanjuti hal tersebut berdasarkan Peraturan Pemerintah Nomor 37 Tahun 2007 Tentang Pelaksanaan UU Nomor 23 Tahun 2006 Tentang Administrasi Kependudukan, maka pemerintah Kecamatan Tanjung Lago Kabupaten Banyuasin telah memberlakukan Peraturan Daerah Nomor 05 Tahun 2008 tentang administrasi kependudukan. Dengan disahkannya Perda Nomor 05 Tahun 2008 proses Pelaksanaan Administrasi Kependudukan yang dulunya dilaksanakan oleh pihak kecamatan berubah ke instansi pelaksanaan yakni Dinas Kependudukan dan Pencatatan Sipil adalah:

a. Perumusan kebijakan teknis dalam bidang pendaftaran penduduk, pecatatan sipil dan pengelolaan dan informasi administrasi kependudukan.

b. Melaksanakan urusan pemerintah dan pelayanan umum dibidang pendaftaran penduduk, pencatatan sipil dan informasi administrasi kependudukan.

c. Membina dan melaksanakan tugas pendaftaran Penduduk dan Pencatatan Sipil.

d. Melaksanakan urusan penatausahaan dinas.

e. Melaksanakan tugas- tugas lain yang diberikan oleh pimpinan sesuai dengan tugas dan fungsinya. 


\section{Perekaman E-KTP}

Dalam pencapaian target Ada tiga unsur yang memegang peranan penting perekaman e-KTP, seperti konsorsium, Pemerintah Daerah dan Pemerintah Pusat. sebagian besar merupakan fungsi dari tim supervisi sebagai representasi dan pemegang peran kunci dalam mensukseskan program nasional e-KTP agar ketiga unsur ini dapat mengimplementasikan tugas dan fungsinya, maka. $\square$.

Agar tidak ada penyalahgunaan pelayanan e-KTP, seluruh rantai proses pelayanan dan penerbitan e-KTP harus disupervisi secara ketat dan menyeluruh. Untuk itu, tim supervisi perlu memahami alur proses dan mensupervisi agar proses perekaman data penduduk dan pengiriman data hasil perekaman di daerah berjalan lancar secara baik dan benar. Selain itu, perlu secara periodik mereview permasalahan teknis dan non teknis yang terjadi dan memberikan masukan rekomendasi pemecahan masalah kepada Ditjen Kependudukan dan Pencatatan Sipil (Dukcapil).

Layanan Keliling Rekam e KTP yang berlangsung di Kantor Camat Tanjung Lago di Jl. Tanjung Api-Api Km 9,5. Dalam proses pelaksanaan pelayanan keliling dalam perekaman e-KTP di Kecamatan Tanjung Lago yang sampai saat ini berjalan masih dijumpai beberapa permasalahan. Pertama, banyak warga masih mengeluh tentang layanan publik yang tidak memadai untuk mendukung pelayanan keliling perekaman e-KTP. Mereka mengeluhkan layanan publik yang ditawarkan oleh pemerintah. Beberapa orang di desa (kepala desa) membayar biaya ilegal ketika mengambil e-KTP. Ada biaya Rp standar untuk setiap akuisisi e-KTP. Bahkan jika e-KTP gratis, pemerasan ini adalah 20.000 per orang. Banyak warga bahkan tidak puas dengan layanan distribusi e-KTP di kantor desa. Selain pemerasan (tuduhan ilegal), hampir semua petugas Kerlahan tidak cukup ramah untuk melayani masyarakat.

\section{B. Metode Penelitian Pendekatan Penelitian}

Dasign penelitian yang akan digunakan adalah metode kualitatif dengan pendekatan fenomena logis naturalistik. Pemilihan pedekatan penelitian ini didasarkan atas pertimbangan bahwa data yang hendak dicari dalam Pelaksanaan Kegiatan Pelayanan Keliling Perekaman E-KTP di Kecamatan Tanjung Lago adalah data yang menggambarkan pelaksanaan proses pendekatan ini juga bertujuan untuk memperoleh pemahaman dan penafsiran secara mendalam dan natural tentang makna yang ada di lapangan. Oleh karena itu peneliti harus turun sendiri ke lapangan aktif mendengar, mengamati, bertanya, mencatat, terlibat, 
menghayati, berfikir dan menarik inferensi dari apa yang diperoleh di lapangan.

\section{Ruang Lingkup Penelitian}

Ruang lingkup penelitian digunakan sebagai pembatasan masalah yang diteliti sehingga penelitian yang dilakukan tidak menyimpang dari tujuan Penelitian ini akan dilakukan di Kantor Camat Tanjung Lago dan sebagai Ruang Lingkup penelitian yang hendak diteliti adalah Pelaksanaan Kegiatan Pelayanan Keliling Perekaman E-KTP di Kecamatan Tanjung Lago.

\section{Variabel Penelitian}

1. Klasifikasi Variabel

2. Defenisi Konseptual

3. Definisi Operasional Unit Analisis

Unit analisis dalam penelitian ini adalah Kecamatan Tanjung Lago.

\section{Informan}

Informan dalam penelitian ini adalah sebagai berikut :

1. Camat Kecamatan Tanjung Lago

2. Lurah/ Kepala Desa yang ada di Kecamatan Tanjung Lago

3. Kepala Disdukcapil (Dinas Kependudukan dan Catatan Sipil) Kabupaten Banyuasin

4. Petugas Perekaman E-KTP Keliling di Kecamatan Tanjung Lago

5. Tokoh Masyarakat (RT,RW)

6. Masyarakat

Jenis dan Sumber Data

a) Jenis Data Data Kuantitatif dan Data Kualitatif, adalah data dalam bentuk kata, kalimat dan gambar.

b) Sumber data

a. Data primer

b. Data sekunder

\section{Teknik Pengumpulan Data}

Peranan data dalam suatu penelitian merupakan sumber pelengkap utama yang mutlak diperlukan, terutama untuk menjelaskan dan mendukung terhadap pertanyaan yang telah dirumuskan dan diidentifikasi pada bab satu dimuka. Sugiyono (2012:253)

Adapun teknik pengumpulan data yang penulis pergunakan adalah sebagai berikut: 
1. Wawancara

2. Observasi

\section{Teknik Analisis Data}

1. Reduksi data;sebagai proses pemilihan, pemusatan perhatian pada penyederhanaan, pengabstrakan, dan transformasi data "kasar" yang muncul dari catatan-catatan tertulis di lapangan.

2. Sajian data; serangkaian informasi terstruktur yang memberi kemungkinan adanya penarikan kesimpulan dan pengambilan tindakan.

3. Kesimpulan/ Verifikasi data; penarikan kesimpulan suatu kegiatan dari konfigurasi yang utuh.

\section{Hasil Penelitian dan Pembahasan}

Dalam pengurusan e-KTP di Kecamatan Tanjung Lago masih ditemukan hambatan di lapangan yang dilakukan petugas di Kecamatan. Kelemahan ini yaitu masyarakat yang datag ke Kantor Kecamatan untuk mengurus e-KTP sesuai jadwal tidak mendapatkan pelayanan yang baik. Aparatur terksesan acuuh di dan operator juga mengeluhkan kewenangan daerah untuk mencetak e-ktp langsung terkendala Mesin cetak E-KTP yang berada di Pusat.

Berikut adalah Analisis Pelaksanaan Kegiatan Pelayanan Keliling Perekaman E-KTP di Kecamatan Tanjung Lago dideskripsikan dengan empat indikator yang dikemukakan oleh Terry ,(2000), yaitu:

1. Perencanaan

\section{a. Dokumen Perencanaan kegiatan Pelayanan}

Dalam pelaksanaan tugas-tugas umum pemerintahan berkaitan erat dengan Fungsi pelayanan masyarakat (public services function). Sistem Administrasi Kependudukan yang sejalan dengan kemajuan teknologi informasi dan komunikasi untuk memenuhi tuntutan masyarakat atas pelayanan kependudukan yang profesional. Seperti yang dikatakan oleh Camat Kecamatan Tanjung Lago, serangkaian kegiatan penataan dan penertiban dokumen dan data kependudukan melalui pencatatan sipil, pendaftaran penduduk, pengelolaan informasi administrasi kependudukan serta pendayagunaan hasilnya untuk pelayanan publik dan pembangunan sektor lain disebut administrasi Kependudukan. Permasalahannya di Kecamatan Tanjung Lago, masyarakat terkesan malas untuk melakukan perekaman e-ktp karena aparatur pemerinta Kedcamatan terkesan acuh oleh karena itu dalam pelayanan pembuatan EKTP dari pemerintah yang ada di Kecamatan Tanjung Lago harus dapat memberikan pelayanan yang terbaik untuk masyarakat yang ada. 


\section{b. SDM}

Sumber daya manusia dalam penelitian yang dimaksud adalah pegawai Kecamatan yang merupakan tolak ukur keberhasilan perekaman e-KTP di Kecamatan. dalam menjalankan tugas sering mengalami kendala dan pada giliranya kualitas layanan yang diberikan kurang optimal. Seperti halnya yang terdapat dikantor Kecamatan Tanjung Lago belum semua aparatur memiliki kompetensi profesional. Selain itu Adanya keluhan dari masyarakat, seperti kekecewaan terhadap pelayanan yang kurang ramah dari aparatur pemerintahan di Kecamatan Tanjung Lago, Untuk menunjang kelancaran pelayanan pembuatan e-KTP diperlukan petugas yang memiliki kemampuan yang handal atau dengan kata lain didukung dengan kemampuan yang yang dapat diandalkan,akurat dan konsisten dalam menjalankan tugas secara profesional. sebagaimana yang kemukakan pada latar belakang penelitian bahwa untuk mendukung kelancaran pelayanan hendaknya perlu dipersiapkan sumber daya aparatur yang berkualitas. Pada umumnya keberadaan aparatur dilembaga publik belum semuanya memiliki kopetensi profesional. Karena itu.

\section{c. Sarana dan Prasarana}

Sarana dan prasarana yang dimaksud untuk menunjang pelaksanaan perekaman e-Ktp adalah seperti ruang tunggu antrian, ruang menyusui bagi ibu hamil, took ATK, kantin, toilet, parkir, layanan khusus, layanan antrian, dan juga genset jika diperlukan Selain itu juga alat cetak E-Ktp.

\section{Pengorganisasian}

a. Struktur Organisasi

Struktur Organisasi atau biasa disebut kegiatan kerja organisasi atau sejenis saling berhubungan dan dapat dikerjakan bersama. Keberadaan aparatur di Kecamatan belum semuanya memiliki kompetensi profesional. Oleh sebab itu itu tidaklah heran ketika dalam menjalankan tugas sering mengalami kendala dan pada giliranya kualitas layanan yang diberikan kurang optimal. Seperti halnya yang terdapat

dikantor Kecamatan Tanjung Lago belum semua aparatur memiliki kopetensi profesional. Data secara tidak langsung menunjukkan sebagian besar legalitas pelatihan yang dimiliki pegawai terbatas, sehingga merefleksi kinerja aparatur dalam layanana publik kurang optimal. Hal ini akan tercermin pada struktur formal suatu organisasi dan tampak atau ditunjukkan oleh bagan suatu organisasi..

\section{b. Pembagian Tugas}

Pembagian Tugas adalah perincian tugas pekerjaan agar setiap individu pada organisasi bertanggung jawab dalam melaksanakan sekumpulan kegiatan. Pembagian tugas sudah ada bagiannya masing- 
masing. Yang menjadi kendala Program perekaman e-KTP terkesan terburu-buru untuk di implementasikan dengan bukti adanya pengunduran program sampai pada 31 Desember 2018 karena jumlah penduduk pada saat rekapitulasi tahun 2017 tidak ditargetkan atau di asumsikan sesuai dengan jadwal implementasi program.

\section{Pergerakan (Actuating)}

a. SOP (Standar Operasional Prosedur)

Standar Operasional Prosedur dalam penelitian yang dimaksud adalah SOP. Cara perekaman e-KTP (KTP Elektronik), Pelayanan dibuka dari pagi jam 08.00 hingga selesai, bahkan sampai malam hari jika banyak yang datang melakukan perekaman. selain itu juga pengambilan sidik jari dan scan retina mata yang bertujuan agar tercipta data tunggal, yaitu setiap satu orang dengan satu identitas (KTP). Namun karena keterbatasan alat perekam, maka mengantri menunggu giliran. Banyaknya wajib e-KTP yang ingin segera melakukan perekaman berakibat antrian di kantor Kecamatan. Hal ini mengakibatkan ada penduduk yang mengurungkan niat melakukan perekaman. Untuk itu Pelayanan keliling perekaman e-KTP dilaksanakan di setiap Kecamatan.

\section{b. Penjadwalan Perekaman E-KTP}

Camat Tanjung Lago menuturkan, dalam proses penjadwalan Undangan perekaman mencantumkan tempat, dan tanggal perekaman. Masing-masing penduduk menerima satu undangan dan jalan yang dilalui sebagian masyarakat desa yang cukup jauh di wilayah Kecamatan Tanjung Lago menjadikan beban biaya transportasi bagi warga yang mengurus e-KTP cukup tinggi. Inipun karena operator kecamatan melakukan jemput bola ke dusun-dusun wilayah khususnya Desa Tanjung Lago sendiri. Dua orang tenaga operator yang dimiliki, statusnya belum jelas karena tidak ber-SK. Sementara ini, kami cukup kebingungan untuk membayar honor mereka. Padahal tenaganya sangat dibutuhkan. Penjadwalan Perekaman E-KTP di Kecamatan Tanjung Lago dijadwalkan seharusnya dari Pukul 07.30 s/d 17.00 WIB (Dapat diteruskan sampai malam hari tergantung kondisi dilapangan) setiap hari. Namun yang terjadi dilapangan sebagian masyarakat yangn telah mendapat undangan untuk perekaman masih saja lama menunggu antrian jadwal perekaman.

\section{Pengawasan}

\section{a. Tanggung Jawab Aparatur Pelayanan Perekaman}

Tanggung jawab Aparatur Pelayanan Kecamatan Tanjung Lago yang terdiri dari 13 desa dan masalah di Kecamatan Tanjung lago adalah kelalaian pegawai tidak memberikan undangan pembuatan e-Ktp kepada masyarakat serta penduduk Kecamatan Tanjung Lago yang sebagian masih berada diluar kota, dan beberapa masyarakat yang kehilangan data 
(Nomor Induk) yang terlaksana masih sekitar 75\%, itu semua. Alasannya karena sebagian masyarakat yang memiliki lapangan pekerjaan di pasar dan ada sebagian masyarakat yang bercocok tanam dalam jangka waktu yang cukup lama dan sumber daya pemerintah kecamatan Singkil yang dilihat dari identitas pegawainya. Serta sikap atau karakteristik aparat pemerintah dalam pelaksanaan pelayanan e-Ktp, dan aspek Pergerakan dilihat dari pelaksana dan mekanisme dan prosedur pelayanan pelaksanaan program e-Ktp untuk masyarakat yang berhalangan hadir.

\section{b. Laporan Kegiatan Perekaman Keliling}

Dalam laporan perekaman e-ktp, Pengurusan e-KTP di seluruh kecamatan di Indonesia yang tanpa dipungut biaya administrasi saat ini, membuat animo masyarakat sangat tinggi untuk segera mengurus dan mendapatkan e-KTP tersebut. Hanya saja, dalam pengurusan e-KTP ini, masih ditemukan kelemahan-kelemahan di lapangan yang dilakukan petugas di Kecamatan. Kelemahan ini antara lain seperti masyarakat yang mendatangi kantor camat untuk mengurus e-KTP sesuai jadwal yang telah ditetapkan, ternyata tidak mendapatkan pelayanan maksimal..

\section{Kesimpulan dan Saran}

Kesimpulan dari penelitian pelaksanaan pelayanan keliling dalam perekaman e-KTP di Kantor Kecamatan Tanjung Lago, dalam implementasinya, masih ada beberapa macam hambatan, seperti kurangnya pemahaman tentang manajemen alat teknologi dalam penciptaan e-KTP oleh karyawan dalam pembuatan kartu penduduk elektronik di kantor Kecamatan Tanjung Lago, belum lagi kurangnya komputer di kantor-kantor di distrik Kecamatan Tanjung Lago, mengakibatkan antrian panjang orang yang akan mengurus e-KTP, masih dibatasi oleh peralatan / perangkat e-KTP yang dapat dengan mudah rusak kecuali itu, yang lain masalah orang yang akan melakukan perekaman e-KTP, di mana masyarakat merasa malas datang ke kantor layanan aparatur yangn terkesan acuh dalam pengurusan e-KTP, sedangkan untuk datang kekantor masyarakat memiliki kegiatan alasannya mencari nafkah dengan bekerja, masalah lain untuk bagian percetakan untuk e-KTP di pusat, ini tentu akan sangat mempengaruhi antusiasme masyarakat untuk membuat atau merekam e-KTP. Untuk itu Diperlukan petugas yang ramah, memiliki kemampuan yang handal, akurat dan konsisten dalam menjalankan tugas secara profesional agar masyarakat merasa nyaman untuk dalam pembuatan e-KTP, sarana prasarana untuk menunjang proses perekaman e-ktp agar kekeliruan data tidak terulang lagi. Serta tersedianya jaringan komunikasi internet yang lancar supaya tidak menjadi kendala dalam penginputan data. 


\section{DAFTAR PUSTAKA}

\section{Buku :}

Al Fatta, Hanif. 2007. Analisis dan Perancangan Sistem Informasi.

Yogyakarta: Andi Offset

Alfandi. Safuan. Kamus Lengkap Bahasa Indonesia. Solo: Sendang Ilmu

Arikunto, Suharsimi, 1998. Prosedur Penelitian Suatu Pendekatan Praktik. Jakarta : Bina Aksara.

George R. Terry ,2000. Prinsip-Prinsip Manajemen. (edisi bahasa Indonesia). PT. Bumi Aksara: Bandung.

Hasan M. Iqbal. 2002. Pokok - Pokok Materi Metodologi Penelitian dan Aplikasinya. Ghalia Indonesia (Anggota IKAPI). Yogyakarta.

Hasibuan Malayu. 2003. Manajemen (Dasar, Pengertian dan Masalah).

Bumi Aksara. Jakarta.

Jhon Salindeho, 1998. Tata Laksana Dalam Manajemen, Sinar Grafika, Jakarta.

Miles, Matthew B dan A. Michael Huberman, 1992. Analisis Data Kualitatif.

Jakarta: Penerbit Universitas Indonesia.

M.Manullang, Dasar-Dasar Manajemen, Ghalia Indonesia, Jakarta, 1995, hal.18.

11 Sujanto, Op.Cit, hal.13. 12

Miles, M.B. and Huberman, A.M. (1984). Qualitative Data Analysis: A Sourcebook of New Methods. Beverly Hills CA: Sage Publications.

Daft, Richard L. 2002. Manajemen Edisi Kelima Jilid Satu. Jakarta : Erlangga.

Semil, Nurmah.Dkk. 2014."Buku Pedoman Penulisan Tesis”. Palembang :

Universitas Pascasarjana STISIPOL Candradimuka

Siagian, Sondang P. 2014. Sistem Informasi Manajemen. Bumi Aksara.

Jakarta

Sinambela, Lijan Poltak. 2010. Reformasi Pelayanan Publik; Teori,

Kebijakan dan. Implementasi. Jakarta: PT. Bumi Aksara

Sugiyono, 2011. Metode Penelitian Kuantitatif, Kualitatif dan R\&D. Bandung: Alfabeta.

Sugiyono, 2012. Memahami Penelitian Kualitatif.Bandung: Alfabeta.

\section{Jurnal :}

Dwi, Jatmiko. 2012. KualitasPelayanan Kartu Tanda Penduduk (KTP) Dalam Grobogan

Meningkatkan Kepuasan Masyarakat (Studi di Kecamatan 
Kabupaten Grobogan). Semarang: Universitas 17 Agustus 1945.

Haq, Saiful, Agus Suharsono, Suji. 2014. Kualitas Pelayanan Pubik Dalam

Pembuatan e-KTP Pada Kecamatan Suboh Kabupaten Situbondo. Jember:

Universitas Jember.

\section{Perundang-Undangan}

Peraturan Pemerintah Republik Indonesia Nomor 37 Tahun 2007 tentang Pelaksanaan Undang-undang Nomor 23 Tahun 2006 Tentang Administrasi Kependudukan.

Peraturan Presiden Nomor 26 Tahun 2009 yang telah di ubah dengan

Peraturan Presiden Nomor 35 Tahun 2010 Tentang Penerapan

Kartu Tanda Penduduk Berbasis Nomor Induk Kependudukan Secara Nasional.

Peraturan Daerah Nomor 10 Tahun 2010 tentang Penyelenggaraan

Administrasi Kependudukan.

Undang-undang No. 25 Tahun 2009 tentang Pelayanan Publik

Undang - Undang Nomor 23 Tahun 2006 Tentang Administrasi

Kependudukan.

Undang-undang Nomor 24 Tahun 2013 Tentang Catatan Sipil.

Undang-undang Nomor 23 Tahun 2014 Pasal 344 ayat (2) tentang

Pemerintah Daerah

\section{Website :}

http://sisteminformasi.blog.binusian.org/2014/04/12/evaluasiimplementasi-e-ktp-di-indonesia/ diakses tanggal 2 Februari 2020 http://repository.uin-suska.ac.id/4069/3/BAB\%20II.pdf diakses tanggal 2 Februari 2020

http://kec-muarasugihan.banyuasinkab.go.id/ diakses tanggal 3 Februari 2020

http://digilib.unila.ac.id/16188/13/BAB\%202.pdf diakses tanggal 12 Februari 2020

http:// dispendukcapil.surakarta.go.id/20XIV/index.php/id/pelayanankami/kependudukan/ektp diakses tanggal 27 Februari 2020 